\title{
Does deregulation work?
}

\section{European airlines are sheltering behind cosy cartels by saying that deregulation in the United States has merely restored the status quo. They should look again.}

Curious things have happened in the United States in the four years following the deregulation of airlines. At the outset, there were a dozen or so large and a host of smaller airlines competing for the domestic market within tight rules set by the regulatory authorities, whose effects were to say which carriers might fly how often between which airports. In the belief that regulations are irksome, and that their abolition would contribute to the more efficient use of a modern technology, the US administration decided to sweep away all but the rules requiring that airlines should comply with the regulations on which people's safety depends.

The outcome has had much of the excitement of a poker game. First, there sprang up a clutch of new airlines to service previously neglected markets. Frontier Airlines, for example, set out to serve the northern plains states and parts of Canada, and New York Air to demonstrate what the established airlines might have worked out for themselves, that there is a demand for air travel over short-haul routes along the eastern seaboard of the United States. Other new airlines set out to compete with the establishment over longer profitable routes: People Express, for example, first became a legend because of the cheapness of its transatlantic fares and then because of its style, that of a high-tech commune. But then, as the financial strains of competition began to tell, some airlines began to swallow others. The biggest player has been the previously regional airline called Texas Air, which has successively swallowed up Continental, New York Air, Eastern and, now, People Express (which had itself swallowed Frontier Airlines). So has the wheel turned full circle, with the United States still served by a dozen or so large and a host of smaller airlines?

That is what the cynics, disbelievers and opponents of airline deregulation say. But there is a crucial difference between the former and the present states of the US airline industry. Now, in particular, there is no reason why new airlines should not again spring up to serve parts of the US market that are either neglected or so profitable that newcomers can persuade their bankers that they have a sporting chance of winning profitable business. For as long as deregulation persists, this facility will be a thorn in the flesh of the complacent and the inefficient.

Sadly, the chance now seems to be evaporating that this simple truth would be appreciated in Europe, where air transport is regulated by means of bilateral cartels between governments on behalf of national carriers, many of them nationalized industries. The most obvious consequence of these arrangements is that air fares in Europe are scandalously high. There is no simple way of telling how much inefficiency shelters behind the network of arrangements requiring that pairs of airlines should share revenues on some profitable routes, that the numbers of airline seats on offer should be kept within predetermined limits or that, in at least one notorious case involving the Irish airline Aer Lingus, that there should be an annual payment to another airline for staying away from Dublin. Nor is it known how many potential travellers are kept on the ground by needlessly high fares. But the over-regulation of Europe's airline business must be one of the most effective ways of wasting European resources.
The European Commission has at last woken up to the dangers. Earlier this year, the Commission warned many of the most wayward airlines that their practices offend against the Treaty of Rome, the basis of the European Economic Community which is also a tract against restraints on competition. Before that, to their credit, the governments of Britain and of the Netherlands had taken the lead in trying to beat the system as it has ossified, by using cheap fares between London and Amsterdam as ways of undercutting other airlines' prices. Both governments have also done stalwart propaganda against the presen 1 network of corrupt arrangements, which is why many well. wishers had been hoping that the British presidency of the European Communities during the six months ending on 31 December would see a shake-up in the European airline business. Naturally, the problem cannot be solved simply. Established airlines are powerful vested interests in themselves, but they often command the affection of those who see them as extensions of the national flag and are an important source of jobs in depressed economies. But over time, it should be possible for a group of nations such as the members of the European Communities, united as they are by their wish to prosper, to put an end to this wasteful duplication and feather-bedding.

To judge from the British proposals for reform presented at a Community meeting last week, the well-wishers will be disappointed. The proposals consist largely of suggestions that airline routes now regulated by $50: 50$ revenue sharing should allow for some slack at the margins, so that ratios of 55:45 either way might be allowable. The steel seems to have gone out of those who were demanding, only a few months ago, that airlines with spare capacity should be free to deploy it where they chose. At least a part of the reason for the change of heart seems to have been the spectacle of the poker game played in the United States, but there are also dark hints that the British government is anxious not to change the rules in a way that would depress the planned sale of shares in the British nationalized airline, British Airways, later in the year. That would be so discreditable that it cannot be believed.

\section{Japanese distinction}

\section{Mr Nakasone can have meant only that Japanese are better educated than Americans.}

Mr Yasuhiro Nakasone, the Japanese prime minister, is in many people's view the best thing to have happened to Japan since the invention of the transistor (at the then Bell Research Laboratories). His qualities as a modern Japanese (he was the minister responsible for science and technology in the crucial period fifteen years ago) and as a courageous politician have won him, in the past few weeks, his party's consent that he should stay on as leader (and thus as prime minister) for an extra year. How does a sensible fellow like that become embroiled in a peculiarly Japanese version of the old nature/nurture argument about the evolution of human intelligence?

With all the fuss of the past few days, it is probably now too late to tell precisely what Mr Nakasone told the young members 